\title{
Effect of Climatic Factor and Date of Sowing on Wheat Crop in Allahabad Condition, Uttar Pradesh, India
}

\author{
Devesh Kumar Agrawal and Satyendra Nath* \\ Department of Environmental Science and NRM, College of forestry, SHUATS, \\ Allahabad-211007, U.P., India \\ *Corresponding author
}

\section{A B S T R A C T}

\section{Keywords \\ Wheat, Climatic condition, Growth, Yield, Correlation \\ Article Info \\ Accepted: \\ 12 August 2018 \\ Available Online: \\ 10 September 2018}

Field experiment was conducted on "Effect of climatic factor and date of sowing on wheat crop in Allahabad condition, Uttar Pradesh" at Forest Nursery, College of Forestry, Sam Higginbottom University of Agriculture, Technology and Sciences, Allahabad, (U.P.). The objective of this research was to find out the role of date of sowing and climatic factors on different stages in wheat crop. The result of study indicated that after date of sowing, the maximum germination of seed was observed within 1-7 days and total $78 \%$ of germination achieved. The increasing trends of plant height were observed in period of 770 days and average 7.47 number of tiller per spike. The observed length of spike 4.81 to 13.86 and number of grain spike ${ }^{-1}$ varied between 23.22 and 93.51 date after sowing. Correlation study were conducted on climatic factor with plant height and number of tillers, results showed that positive correlation between temperature, rainfall and negative correlation with humidity for plant height and number of tillers.

\section{Introduction}

Climate change is not a new phenomenon in the world. The rise in temperature of the earth surface and in atmosphere, fluctuation in rainfall, declining ground water, flooding due to high rainfall, drought, soil erosion, heavy wind, rising sea level due to melting of glacier, cyclone, wind speed, hail storm, fog, earthquake and landslide etc., are all the clear evidence of climate change phenomenon (Ahmad et al., 2011). Climate and its variability impact all sectors of economy in several ways like abnormality in rainfall, results in severity and frequency of floods. Any increment in maximum temperature may increase mean sea levels and it would affect large populations in peninsular and coastal areas. It may increase 15 to $40 \%$ rainfall there and raise the annual mean temperature by 3 to 6 degree (Zhai and Zhuang, 2009). Minimum temperature increased about twice as fast as maximum temperature over global land areas since 1950, resulting in a broad decline in the diurnal temperature range (Folland et al., 2001).

The mean surface air temperature over land areas increased at a rate of about $0.9^{\circ} \mathrm{C}$ per century over the 1950-1993 periods (IPCC, 2001). Climate change is no more a distant problem. The changes in climatic variables, 
such as rising temperature, variable rainfall, frequent droughts, hurricane and typhoons (Lobell et al., 2012; Auffhammer et al., 2011), and have almost failed to reach a global consensus on the mitigation of greenhouse gas (GHG) emissions (Sharma 2015). Indian agriculture is facing challenges due to several factors such as increased competition for land, water and labour from non-agricultural sectors and increasing climatic variability. The latter associated with global warming will result in considerable seasonal/annual fluctuations in food production. All agricultural commodities even today are sensitive to such variability.

Droughts, floods, tropical cyclones, heavy precipitation events, hot extremes and heat waves are known to negatively impact agricultural production, and farmers' livelihood. It is also predicted that a rise in temperature may reduce yields of rice, wheat and other cereals crops (ICRIER et al., 2009). Changes in global climate are likely to influence spatial and temporal trends of temperature and rainfall, which will affect crop phenology and yield (Jalota and Vashisht, 2016).

\section{Materials and Methods}

\section{Experimental Site}

The experiment was carried out during Rabi season 2017-18 at Forest Nursery, Sam Higginbottom University of Agriculture, Technology and Sciences (SHUATS), Allahabad. U.P., which is, located at $25.57^{\circ} \mathrm{N}$ latitude.de $81.50^{\circ} \mathrm{E}$ longitude and $98 \mathrm{~m}$ altitude above the mean sea level. All the facilities, which are required for crop cultivation met out from the Department.

\section{Soil of the experimental field}

Physico-chemical characteristics of the soil, before sowing, soil sample were collected randomly from 0-30 $\mathrm{cm}$ depth from different place in the plots. A representative homogenous composite sample was drawn by mixing these entire soil samples together. This composite soil sample was analyzed to determine the physico-chemical properties of the soil.

\section{Climatic conditions}

Allahabad is located in the south-eastern part of Uttar Pradesh and has tropical to subtropical climate with extremes of summer and winter. During winter months especially Dec-Jan temperature drops down to as low as $5^{\circ} \mathrm{C}$ while in summer temperature reaches above $45^{\circ} \mathrm{C}$.

Hot scorching winds (commonly known as Loo) is regular feature during the summer whereas there may be an occasional spell of frost during the winter. The annual rainfall is $1100 \mathrm{~mm}$ mostly during the monsoon autumn i.e. July-Sept with a few occasional showers during winter months.

The experiment was conducted in one fixed plot with 6 sub-plots and 20 Dec. The plot size of the experimental plot was $2.0 \times 2.0 \mathrm{~m}$ and wheat was shown with spacing of $22.5 \mathrm{~cm}$.

\section{Fertilizer application}

Recommended dose of fertilizer was applied through chemical fertilizers at the time of sowing. The nutrients were applied in the form of urea, Di-ammonium phosphate and Muriate of potash. Nitrogen was applied in three split doses with 50 per cent as basal application, 25 $\%$ at 21 days after sowing and remaining $25 \%$ at 45 days after sowing.

\section{Date of sowing}

Date of sowing (20 ${ }^{\text {th }}$ December, 2017) for present research. 


\section{Results and Discussion}

\section{Germination percentage $(\%)$}

Form the perusal of Table 1, it indicated that the germination percentage of wheat in all sub plots (1-6) under plot 1 . The 100 seeds were taken per sub plots as easy to calculate in germination percentage in 1-7 DAS.

After date of sowing, the maximum germination of seed in subplots 6 and total germination in 1-7 DAS was 9, 11, 12, 12, 13, 10 and $11 \%$ and total percentage of germination after 7 DAS is $78 \%$.It is concluded that the cause of higher germination rate was climate and the active factors are responsible. Similar results were reported by (Sawant et al., 2012; Nadew, 2018)

\section{Plant height}

The change of plant height with the interval of one week is reported in Table 2. Mean value of plant height (centimetre) for the subplot after date of sowing started from 7, 14, 21, 28, 35, 42, 49, 56, 63, 70, 77, 84, 91, 98 and 105 days and corresponding height of plant are 8.34, 17.91, 24.36, 31.49, 38.33, 44.51, 52.57, $60.97,69.12,76.23,81.15,85.41,87.04,87.12$ and $87.14 \mathrm{~cm}$ respectively.

The increasing trends were observed from day 7 to 70 then slightly decreasing trend were observed upto 105 days. The result of present research indicated that wheat crop height increases with time, slightly increasing trends were observed after 70 day of sowing and possible influencing factor for plant growth are solar radiation, temperature, atmosphere condition, rainfall, humidity and soil moisture the region.

Similar research trends was observed by (Nadew, 2018; Suleiman et al., 2014; Maurya et al., 2015).

\section{Number of tillers}

The observation of no. of tillers in the subplots after day of sowing with the interval of one week started from day7to 19, 26, 33, 40, 47, $54,61,68,75,82,89,96$ and 105days. There is no growth observed in tillers during the period 7 to 19 DAS. The average 2.71number of tillers per spike observed after 26 DAS. Then vigorously growth of no. tillers recorded during 26 to 40 DAS then number of tillers/ spike remains same on or after 40 to 105 DAS reported in (Table 2). The major influencing factors for growth of tillers is solar radiation, temperature, atmosphere condition, rainfall, humidity and soil moisture of the region. Similar results finding were reported by (Suleiman et al., 2014)

\section{Length of spike (cm)}

There is no growth in length of spike in 7-55 DAS afterwards 62, 69, 76 83, 90, 97 and 105 DAS length of spike $4.81,6.80,8.84,10.79$, $12.56,13.68,13.86$ respectively (Table 3 ). Slightly increasing trends observed up to 62 DAS then the growth of spikes was increasing weakly, till 105 days after sowing.

The influencing factor for growth of length of spikes is solar radiation, temperature, atmospheric condition, rainfall, humidity and soil moisture the region. Similar results were reported (Vashisht et al., 2018.)

\section{No. of grains spike ${ }^{-1}$}

Table 3 indicated that effect of date of sowing on number of grain/ spike. From the observation it's clearly indicated that after of date sowing to 57 days, there is no grain was observed in spike afterward grain appeared in the spike after 64, 71, 78, 85, 92, 99 and 105 DAS the observed grain in spike is 23.22, 43.39, 54.30, 63.77, 72.74, 85.07, 93.51 grains /spike/plants respectively. 
Table.1 Germination percentage of seed in Subplots after date of sowing (20Dec, 2017)

\begin{tabular}{|c|c|c|c|c|c|c|c|c|c|c|}
\hline Sub Plot & $\begin{array}{c}\text { Total no. of } \\
\text { seeds sown }\end{array}$ & $\begin{array}{c}\mathbf{1 - 7} \\
\text { DAS }\end{array}$ & $\begin{array}{c}\mathbf{8} \\
\text { DAS }\end{array}$ & $\begin{array}{c}\mathbf{9} \\
\text { DAS }\end{array}$ & $\begin{array}{c}\mathbf{1 0} \\
\text { DAS }\end{array}$ & $\begin{array}{c}\mathbf{1 1} \\
\text { DAS }\end{array}$ & $\begin{array}{c}\mathbf{1 2} \\
\text { DAS }\end{array}$ & $\begin{array}{c}\mathbf{1 3} \\
\text { DAS }\end{array}$ & $\begin{array}{c}\text { DAS } \\
\text { DAS }\end{array}$ & $\begin{array}{c}\text { Total Per cent } \\
\text { germination }\end{array}$ \\
\hline S1P1 & 100 & 0 & 09 & 12 & 14 & 12 & 16 & 09 & 11 & \\
\hline S2P2 & 100 & 0 & 11 & 9 & 15 & 13 & 15 & 10 & 13 \\
\hline S3P3 & 100 & 0 & 10 & 12 & 13 & 12 & 14 & 09 & 11 & \\
\hline S4P4 & 100 & 0 & 9 & 13 & 12 & 14 & 14 & 10 & 12 \\
\hline S5P5 & 100 & 0 & 08 & 11 & 13 & 10 & 12 & 13 & 13 & \\
\hline S6P6 & 100 & 0 & 12 & 14 & 09 & 16 & 12 & 11 & 09 & \\
\hline Total & $\mathbf{6 0 0}$ & $\mathbf{0}$ & $\mathbf{5 9}$ & $\mathbf{7 1}$ & $\mathbf{7 6}$ & $\mathbf{7 7}$ & $\mathbf{8 3}$ & $\mathbf{6 2}$ & $\mathbf{6 9}$ & \\
\hline Germination percentage & $\mathbf{0}$ & $\mathbf{9 \%}$ & $\mathbf{1 1 \%}$ & $\mathbf{1 2 \%}$ & $\mathbf{1 2 \%}$ & $\mathbf{1 3 \%}$ & $\mathbf{1 0 \%}$ & $\mathbf{1 1 \%}$ & $\mathbf{7 8 \%}$ \\
\hline
\end{tabular}

Table.2 Effect of date of sowing on plant height and no. of tillers

\begin{tabular}{|c|c|c|c|}
\hline DAS & Plant height & DAS & No. of tillers spike \\
\hline $\mathbf{7}$ & 8.34 & & \\
\hline $\mathbf{1 4}$ & 17.91 & & 0 \\
\hline $\mathbf{2 1}$ & 24.36 & 7 to 19 & 2.71 \\
\hline $\mathbf{2 8}$ & 31.49 & 26 & 5.50 \\
\hline 35 & 38.33 & 33 & 7.43 \\
\hline $\mathbf{4 2}$ & 44.51 & 40 & 7.47 \\
\hline $\mathbf{4 9}$ & 52.57 & 47 & 7.47 \\
\hline $\mathbf{5 6}$ & 60.97 & 54 & 7.47 \\
\hline $\mathbf{6 3}$ & 69.12 & 61 & 7.47 \\
\hline $\mathbf{7 0}$ & 76.23 & 68 & 7.47 \\
\hline $\mathbf{7 7}$ & 81.15 & 75 & 7.47 \\
\hline $\mathbf{8 4}$ & 85.41 & 82 & 7.47 \\
\hline 91 & 87.04 & 89 & 7.47 \\
\hline $\mathbf{9 8}$ & 87.12 & 96 & 7.47 \\
\hline $\mathbf{1 0 5}$ & 87.14 & 105 & \\
\hline
\end{tabular}

Table.3 Effect of date of sowing on length of spike and no. of grain spike ${ }^{-1}$

\begin{tabular}{|c|c|c|c|}
\hline DAS & Length of spike & DAS & No. of grain spike \\
\hline $\mathbf{7}$ to 55 & 0 & 7 to 57 & 0 \\
\hline 62 & 4.81 & 64 & 23.22 \\
\hline 69 & 6.80 & 71 & 43.39 \\
\hline $\mathbf{7 6}$ & 8.84 & 78 & 54.30 \\
\hline $\mathbf{8 3}$ & 10.79 & 85 & 63.77 \\
\hline $\mathbf{9 0}$ & 12.56 & 92 & 72.74 \\
\hline 97 & 13.68 & 99 & 85.07 \\
\hline $\mathbf{1 0 5}$ & 13.86 & 105 & 93.51 \\
\hline
\end{tabular}


Table.4 Effect of date of sowing on yield $\mathrm{q} / \mathrm{ha}$

\begin{tabular}{|c|}
\hline Sub- Plots \\
\hline S1P1 \\
\hline S2P2 \\
\hline S3P3 \\
\hline S4P4 \\
\hline S5P5 \\
\hline S6P6 \\
\hline Total yields
\end{tabular}

\begin{tabular}{|l|}
\hline DAS \\
\hline 38.36 \\
\hline 40.57 \\
\hline 36.23 \\
\hline 41.13 \\
\hline 39.14 \\
\hline 43.24 \\
\hline $\mathbf{3 9 . 7 7}$ \\
\hline
\end{tabular}

Table.5 Correlations between climatic factors and plant height

\begin{tabular}{|c|c|c|c|c|c|c|c|}
\hline \multicolumn{2}{|c|}{ Parameters } & Plant $\mathrm{H}$. & T. $\max$ & T. min & Hum. Morng. & Hum. Eveng. & Rainfall \\
\hline \multirow[t]{2}{*}{ Plant H. } & Pearson Correlation & 1 & & & & & \\
\hline & Sig. (2-tailed) & & & & & & \\
\hline \multirow[t]{2}{*}{ T. $\max$} & Pearson Correlation & $.976^{* *}$ & 1 & & & & \\
\hline & Sig. (2-tailed) & .000 & & & & & \\
\hline \multirow[t]{2}{*}{ T. min } & Pearson Correlation & $.944^{* *}$ & $.962^{* *}$ & 1 & & & \\
\hline & Sig. (2-tailed) & .000 & .000 & & & & \\
\hline \multirow{2}{*}{$\begin{array}{l}\text { Hum. } \\
\text { Morng. }\end{array}$} & Pearson Correlation & $-.985^{* *}$ & $-.968^{* *}$ & $-.916^{* *}$ & 1 & & \\
\hline & Sig. (2-tailed) & .000 & .000 & .000 & & & \\
\hline \multirow{2}{*}{$\begin{array}{l}\text { Hum. } \\
\text { Eveng. }\end{array}$} & Pearson Correlation & $-.857^{* *}$ & $-.837^{* *}$ & $-.732^{* *}$ & $.891^{* *}$ & 1 & \\
\hline & Sig. (2-tailed) & .000 & .000 & .002 & .000 & & \\
\hline \multirow[t]{2}{*}{ Rainfall } & Pearson Correlation & .326 & .293 & .436 & -.210 & .002 & 1 \\
\hline & Sig. (2-tailed) & .235 & .289 & .104 & .452 & .995 & \\
\hline
\end{tabular}

Table.6 Correlations between active factors and no. of tiller on date of sowing

\begin{tabular}{|c|c|c|c|c|c|c|c|}
\hline \multicolumn{2}{|c|}{ Parameters } & \multirow{2}{*}{$\begin{array}{c}\text { No. } \\
\text { Tiller } \\
1\end{array}$} & \multirow[t]{2}{*}{ T. $\max$} & \multirow[t]{2}{*}{ T. min } & \multirow{2}{*}{$\begin{array}{l}\text { Hum. } \\
\text { Morng. }\end{array}$} & \multirow{2}{*}{$\begin{array}{l}\text { Hum. } \\
\text { Eveng. }\end{array}$} & \multirow[t]{2}{*}{ Rainfall } \\
\hline No. Tiller & Pearson Correlation & & & & & & \\
\hline & Sig. (2-tailed) & & & & & & \\
\hline \multirow[t]{2}{*}{ T. $\max$} & Pearson Correlation & .534 & 1 & & & & \\
\hline & Sig. (2-tailed) & .074 & & & & & \\
\hline \multirow[t]{2}{*}{ T. min } & Pearson Correlation & .481 & $.950^{* *}$ & 1 & & & \\
\hline & Sig. (2-tailed) & .114 & .000 & & & & \\
\hline \multirow{2}{*}{$\begin{array}{l}\text { Hum. } \\
\text { Morng. }\end{array}$} & Pearson Correlation & $-.645^{*}$ & $-.961^{* *}$ & $-.874^{* *}$ & 1 & & \\
\hline & Sig. (2-tailed) & .024 & .000 & .000 & & & \\
\hline \multirow{2}{*}{$\begin{array}{l}\text { Hum. } \\
\text { Eveng. }\end{array}$} & Pearson Correlation & -.323 & $-.690^{*}$ & -.561 & $.761^{* *}$ & 1 & \\
\hline & Sig. (2-tailed) & .306 & .013 & .058 & .004 & & \\
\hline \multirow[t]{2}{*}{ Rainfall } & Pearson Correlation & .219 & .261 & .442 & -.131 & .277 & 1 \\
\hline & Sig. (2-tailed) & .494 & .412 & .150 & .686 & .383 & \\
\hline
\end{tabular}


Slightly increasing trends observed upto 64 DAS then the growth of no. of grains spikes ${ }^{-1}$ was increasing weakly, till 105 DAS similar research was conducted by other authors (Suleiman et al., 2014; Neenu et al., 2013)

\section{Grain yield (q/ha)}

The observation of grains yield in plots under subplot presented in Table 4. Variation of yield in subplots reported in Table 4, the yield were observed (36.23-43.24 q/ha) and average yield $39.77 \mathrm{q} / \mathrm{ha}$ for date of sowing $20^{\text {th }}$ December, 2017. Yield in wheat crop is influence by soil characteristics, irrigation scheduling, time of sowing, solar radiation, temperature, rainfall, irrigation, humidity and soil moisture. Similar finding were observed by Nadew (2018), Kaur (2017) and Andarzian et al., (2015).

\section{Correlations studies between plant height and climatic factor}

Temperature, humidity and rainfall are the active factor for growth of plant or crops. Correlation studies were performed on Plant height with other climatic factors minimum temperature, maximum temperature, humidity morning, humidity evening and rainfall. The study results indicate that positive correlation between temperature maximum (0.976), temperature minimum $\left(.944^{* *}\right)$, rainfall with weak positive correlation (.326) and strong negative correlation (-0.985) humidity morning and (-0.857) and positive correlation with rainfall $(0.326)$ for number of tillers for humidity evening reported in Table 5.

\section{Correlation studies between number of tiller and climatic factor}

The temperature, humidity and rainfall are the active factor for growth of plant crops, Perusal of Table 6, Correlation study results showed that positive correlation between temperature maximum (0.534), temperature minimum (.481), rainfall with weak positive correlation(.219) and strong negative correlation (-.645) humidity morning and (.306) for humidity evening and positive correlation with rainfall (0.494) for number of tillers. The similar study was performed by (Khandaker et al., 2009 and Tao et al., 2012).

From the present study it is concluded that date of sowing and climatic factor play a important role on growth of plant or crop from every stages. Result of present study indicated that the percent of germination, plant height, number of tiller, length of spike, number of grain and yields are highly influence on climatic factor and date of sowing. Correlation study also confers that climatic attributes temperature, humidity and rainfall are the active factor for the growth of crops and number tillers in the wheat crop.

\section{References}

Ahmad, J., Dastgir, A. and Haseen, S. (2011) Impact of climate change on agriculture and food security in India', International Journal of Agricultural Environmental and Biotechnology 4 (2):129-137.

Andarzian, B., Hoogenboom G., Bannayan M., Shirali M. and Andarzian B. (2015) Determining optimum sowing date of wheat using CSM-CERES-Wheat model. Journal of the Saudi Society of Agricultural Sciences, 14, 189-199.

Auffhammer M., Ramanathan V. and Vincent J. R. (2011) Climate change, the monsoon, and rice yield in India. Clim. Change 111 (2), 411-424.

Folland C.K. (2001) Observed Climate Variability and Change, in Climate Change 2001: The Scientific Basis, pp. 108-109, Cambridge University Press, Cambridge.

ICRIER (2009) Food security in south Asia: Issues and opportunities by Mittal, Surabhi and Deepti Sethi. Indian Council 
for Research on International Economic Relations, Working paper No. 240.

IPCC (2001) Climate Change 2001: The Scientific Basis. Contribution of Working Group I to the Third Assessment Report of the Intergovernmental Panel on Climate Change, Cambridge University Press, Cambridge, England, 2001, in press.

Jalota S.K., and Vashisht B.B. (2016) Adapting cropping systems to future climate change scenario in three agro-climatic zones of Punjab, India. J. Agrometeorol., 18(1): 48-56.

Kaur C. (2017) Performance of Wheat Varieties under Late and Very Late Sowing Conditions. Int.J.Curr.Microbiol.App.Sci Vol. 6(9): 3488-3492

Khandaker L., Akond A. S. M. G. M. and Shinya O. (2009) Air temperature and sunlight intensity of different growing Period affects the biomass, leaf color and betacyanin pigment accumulations in red amaranth (Amaranthus tricolor L.). Journal of Central European Agriculture Volume 10 No. 4 (439-448).

Lobell D. B., Sibley A. and Ivan O. M. J., (2012) Extreme heat effects on wheat senescence in India. Nat. Clim. Change 2 (3), 186-189

Maurya, S.K., Nath, S., Patra S.S. and Rout S. (2015) Impact of Weather Parameters on Economics of Pearl Millet (Pennisetum glaucum L.) Varieties in Allahabad, Journal of Plant Development Sciences, Vol. 7 (12), pp. 863-868.

Nadew BB (2018) Effects of Climatic and Agronomic Factors on Yield and Quality of Bread Wheat (Triticum aestivum L.) Seed: A Review on Selected Factors. Adv
Crop Sci Tech 6: 356. doi:10.4172/23298863.1000356

Neenu, S., Biswas A.K. and Subba Rao, A (2013) Impact of climatic factors on crop production - a review, agri. reviews, Vol. 34 (2) pp. 97-106

Sawant A. A., Patil S. C., Kalse S. B. and Thakor N. J. (2012) Effect of temperature, relative humidity and moisture content on germination percentage of wheat stored in different storage structures. Agric. Eng. Int: CIGR Journal, Vol. 14, No. 2.

Sharma V.K., (2015) Climate change and its impacts: understanding some facts, myths, and controversies. In: Mahendra Dev, S. (Ed.), India Development Report 2015. Oxford University Press, New Delhi, pp. 271-282.

Suleiman A. A., Nganya J. F., and Ashraf M. A. (2014) Effect of Cultivar and Sowing Date on Growth and Yield of Wheat (Triticum aestivum L.) in Khartoum, Sudan. Journal of Forest Products \& Industries, 3(4), 198-203 ISSN: 23254513

Tao S. Y., Zhou D. W., Zhang H. X. and Guang L. I. D. (2013) Effects of vegetation height and density on soil temperature Variations. Chinese Science Bulletin Vol.58 No.8: 907-912

Vashisht B.B., and Jalota S.K. (2018) Impact of temperature variability and management interventions on productivity of Wheat. Journal of Agrometeorology 20 (1): 11 15.

Zhai F. and Zhuang J. (2009) Agriculture impact of climate change: A general equilibrium analysis with special reference to Southeast Asia, ADBI Working Paper Series 131.

\section{How to cite this article:}

Devesh Kumar Agrawal and Satyendra Nath. 2018. Effect of Climatic Factor and Date of Sowing on Wheat Crop in Allahabad Condition, Uttar Pradesh, India. Int.J.Curr.Microbiol.App.Sci. 7(09): 1776-1782. doi: https://doi.org/10.20546/ijcmas.2018.709.214 